\title{
Observations on the use of the Coulter model D electronic cell counter in clinical haematology
}

\author{
A. N. BLADES AND H. C. G. FLAVELL \\ From the Dorset County Laboratory, Dorchester, Dorset
}

SYNOPSIS The use of the Coulter electronic cell counting machine (model D) in a routine patho logical laboratory is described, as are also the technical details involved.

The principle of the Coulter counter, model $\mathrm{D}$, is that a suspension of particles passes through an orifice, where the particles interfere with the passage of an electric current, producing pulses on an electronic counter. The circuit can be adjusted to vary the critical volume which will just produce a pulse. Alteration of this 'threshold' value enables all particles to be counted, or by raising the threshold, only particles of progressively larger sizes. Both red and white cells may be counted. In counting red cells a correction is necessary because sometimes more than one red cell passes through the orifice at a time, reducing the true total; a table provided by the manufacturers gives the corrections.

\section{RED CELLS}

According to Brecher, Schneiderman, and Williams (1956), the standard error of the red cell count on this machine is $2 \%$. Table I shows the values obtained by examination of the blood of 10 normal healthy male members of the laboratory staff, using the oxyhaemoglobin method, a haematocrit centrifuge, the Coulter red cell counter, and from these calcu-

Received for publication 3 August 1962 lating the indices. The consistency of these results at the expected level confirms that the counter is moreo accurate than the manual methods of counting.

Figure 1 shows a typical red cell threshold curveobtained by progressively raising the threshold. The $\bar{z}$ left-hand part of the curve forms a plateau, showing that the threshold is sufficiently low to count all cells until it is raised to a value of about $12 \cdot 5$. The $\vec{\theta}$ centre of this plateau is the best point for total rede cell counts; at the extreme left there is a certaing amount of electrical interference and false pulses due to particles of dirt, and at the right-hand end the numbers are beginning to fall off due to exclusion of the smallest red cells. Machines vary slightly in the value of their threshold settings.

From readings taken at successive values, the number of cells counted at each value can be plotted. If the value at each threshold is then subtracted from the previous one, a second curve can be constructed, showing the distribution of red cellso according to volume. This curve, also shown in Fig. 1, is fairly symmetrical with a peak in the middle, analogous to the type described by Price-Jones which was, however, based on the red cell diameter, $₹$ whereas this one is based on the red cell volume. It 을

TABLE I

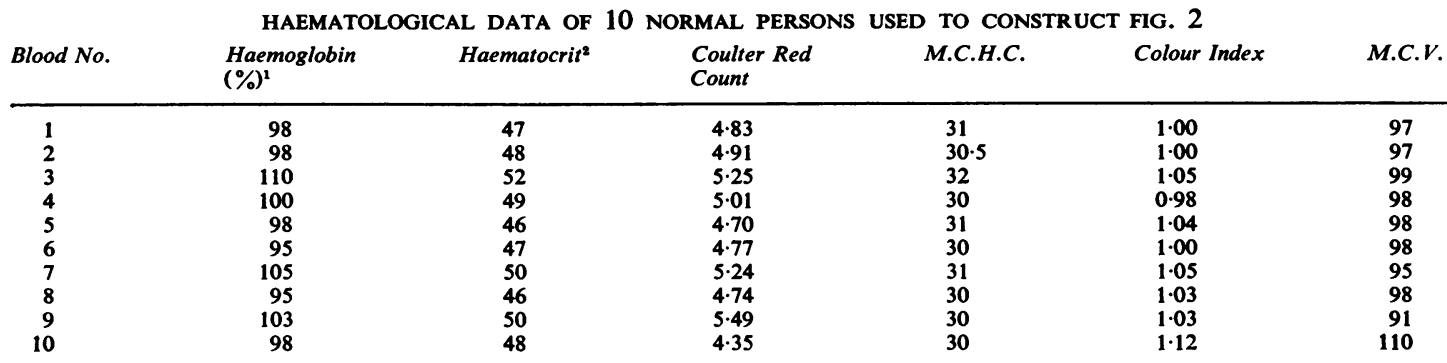

$114.8 \mathrm{~g} . \mathrm{Hb}=100 \%$

${ }^{2}$ Investigations in progress suggest that these values are about 5 to $6 \%$ too high. 
FIG. 1. Example of a normal threshold curve (continuous line $=R . B . C$. in millions) and the derived curve of size distribution (broken line $=10,000$ ).

FIG. 2. Derived curves of the 10 bloods described in the Table. The shaded area includes eight.

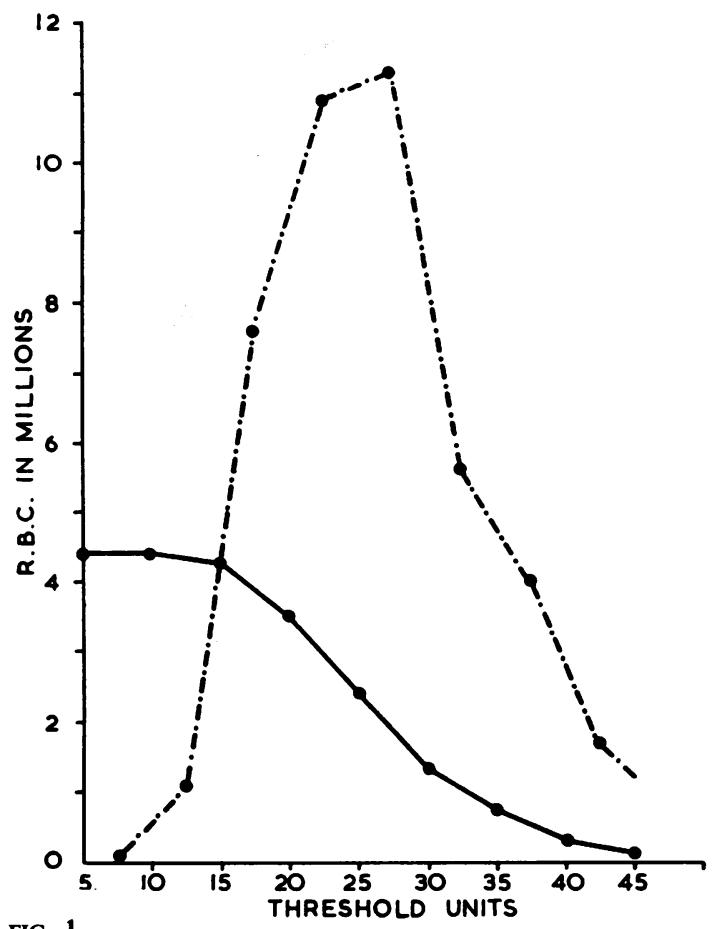

FIG. 1

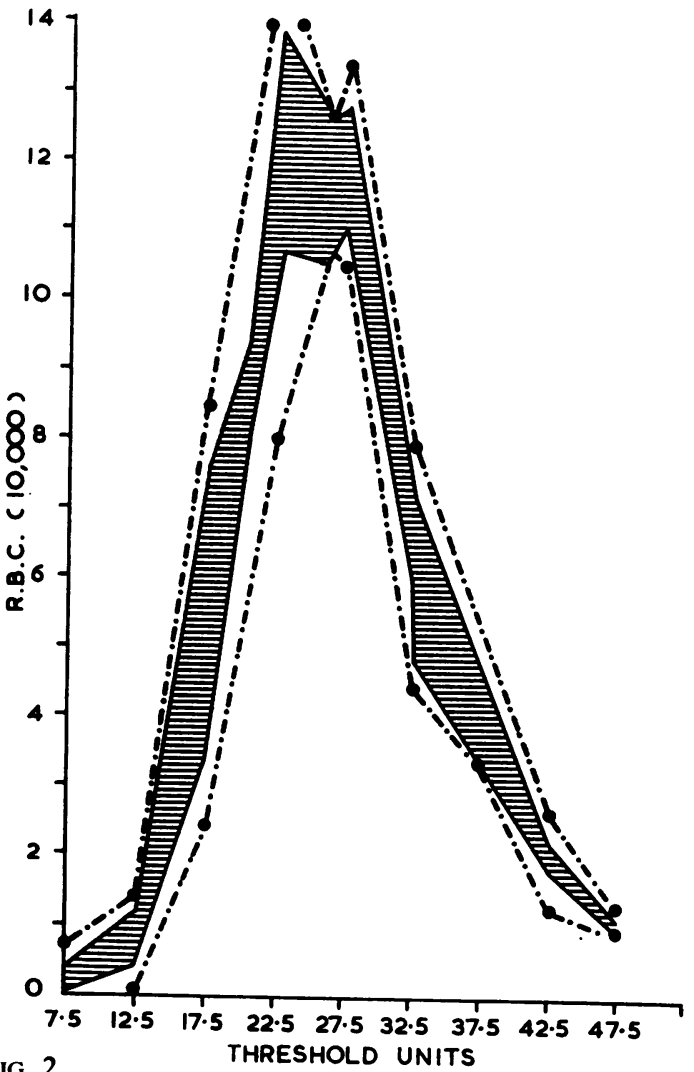

is worth noting that a red cell of $8 \mu$ diameter has about twice the volume of a red cell of $6 \mu$ diameter.

Figure 2 shows the derived curves from the 10 blood samples included in Table I. We have found that a figure of 7.5 on the threshold scale is suitable for counting the total red cells, and that for scanning the size distribution it is convenient to proceed in steps of 5 from 5 to 50 . This produces the figures for calculation of mean cell volume by the method of Magath and Berkson (1960).

\section{ABNORMAL RED CELL PICTURES}

Figures 3, 4, and 5 show typical curves from cases of severe iron deficiency anaemia. The peak is sharp and shifted to the left, i.e., large numbers of small red cells are present and little else. Figures 6, 7, and 8 show curves from cases of macrocytic anaemia. In these the curve is flattened and the peak is shifted to the right, indicating that cells of all sizes are present, but mainly large ones. Figures 9, 10, 11, and 12 are a series taken on the days indicated from a boy of 9

with reticulosarcoma. Ten days before the first one, successful treatment was begun with cyclophosphamide, and the curves show a reticulocyte response with a peak on the right-hand side, which merges in the second one in the main red cell mass, after which the curve returns to normal.

Two examples of polycythaemia investigated have both shown curves similar to those with iron deficiency anaemia but at about twice the height, i.e., cells are microcytic.

\section{MEAN CELL VOLUME}

By the method of Magath and Berkson (1960) the factor necessary to convert the threshold units into cubic microns came to $3 \cdot 74$. To find this involves making red cell corrections on all the separate values, and does not add significantly to the clinical information obtained from the graph. We therefore only correct the total red cell value and draw the graphs on the uncorrected figures. The machine gives an accurate colour index and mean cell volume 


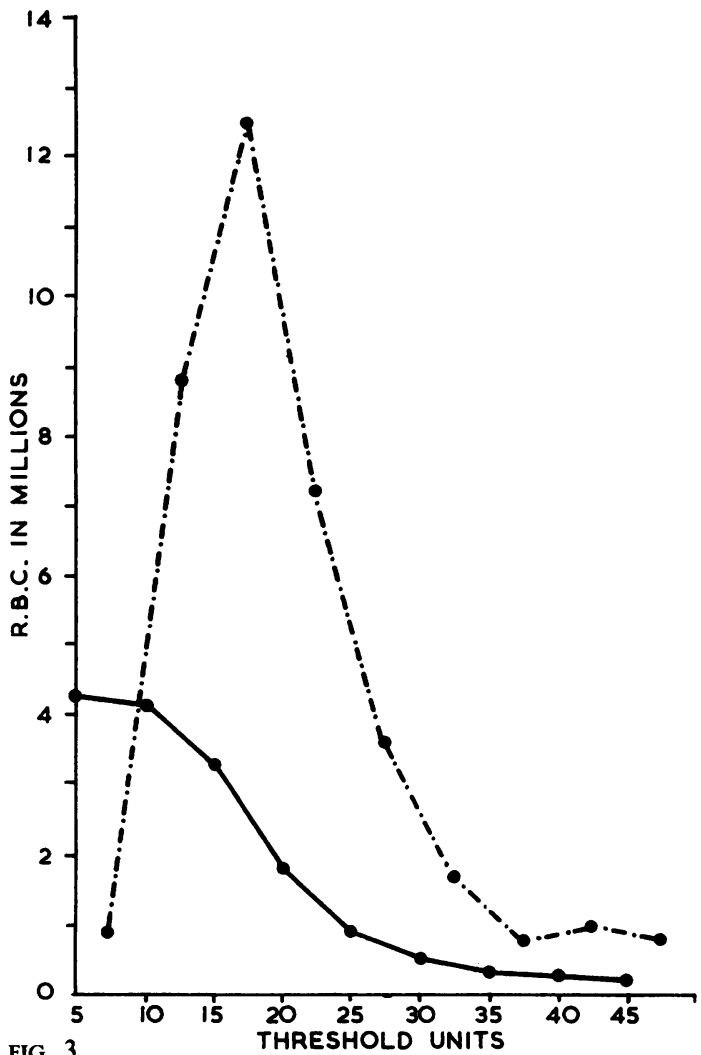

FIG. 3

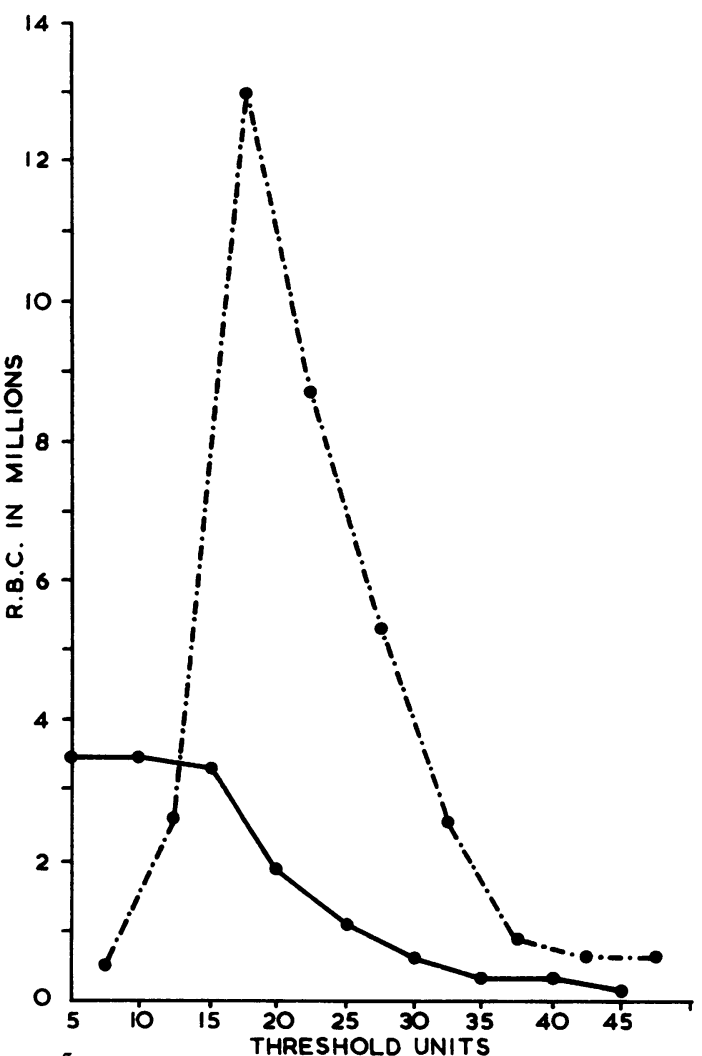

FIG. 5

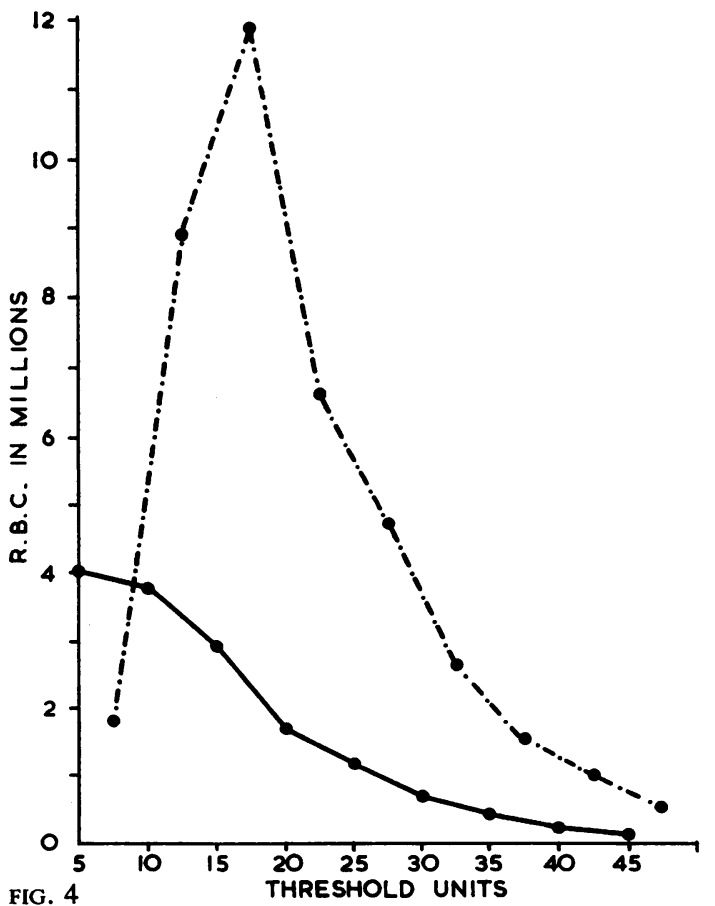

FIG. 3. Iron-deficiency anaemia (scale, etc., as Fig. 1). Hb $56 \%$; P.C.V. $33 \%$; R.B.C. 4.27 m.; M.C.H.C. $25 \%$; M.C.V. $77 \mu^{3}$; colour index 0.66.

FIG. 4. Iron-deficiency anaemia. Hb. $57 \%$; P.C.V. $29 \%$; R.B.C. 3.6 m.; M.C.H.C. $29 \%$; M.C.V. $80 \mu^{3}$; colour N index $0 \cdot 77$.

FIG. 5. Iron-deficiency anaemia. Hb $50 \%$; P.C.V. $32 \%$; N R.B.C. 3.61 m.; M.C.H.C. $23 \%$; M.C.V. $88 \mu^{3}$; colour index 0.68 . 


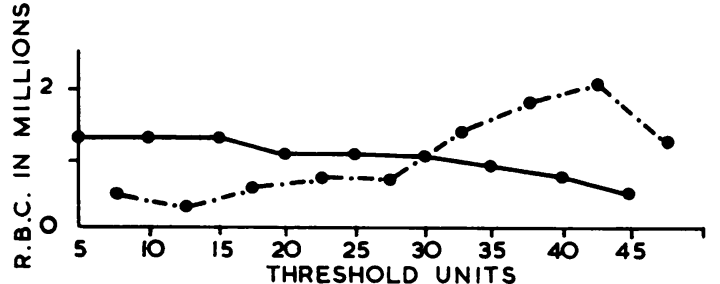

FIG. 6

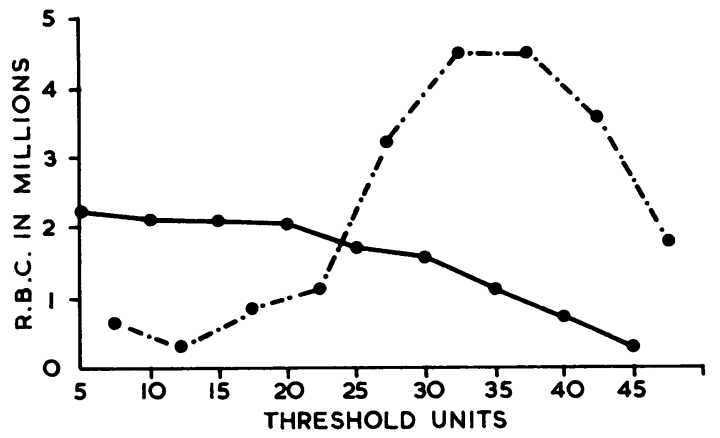

FIG. 7

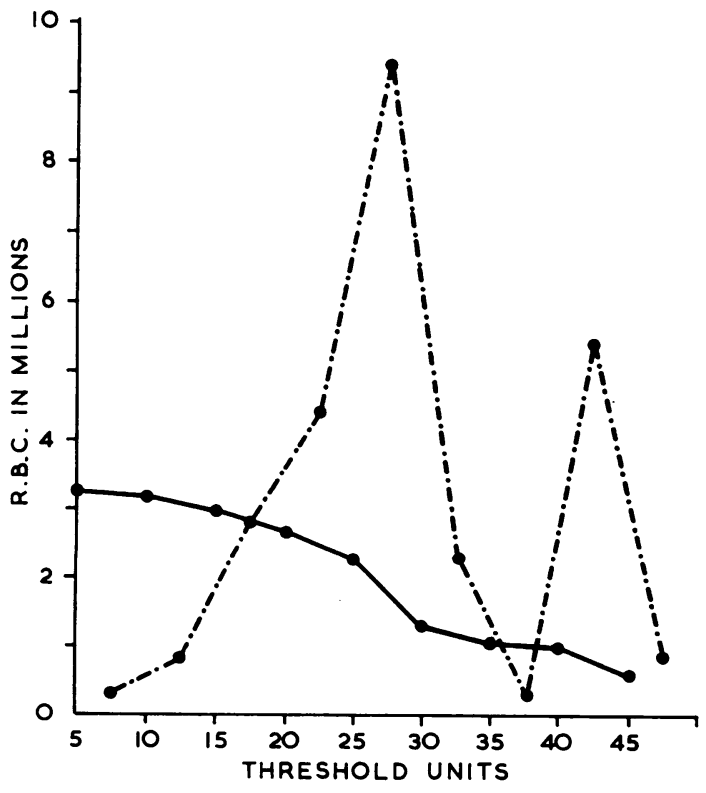

FIG. 8

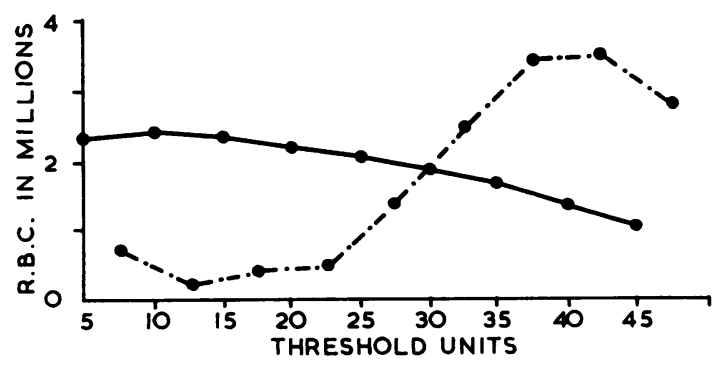

FIG. 9

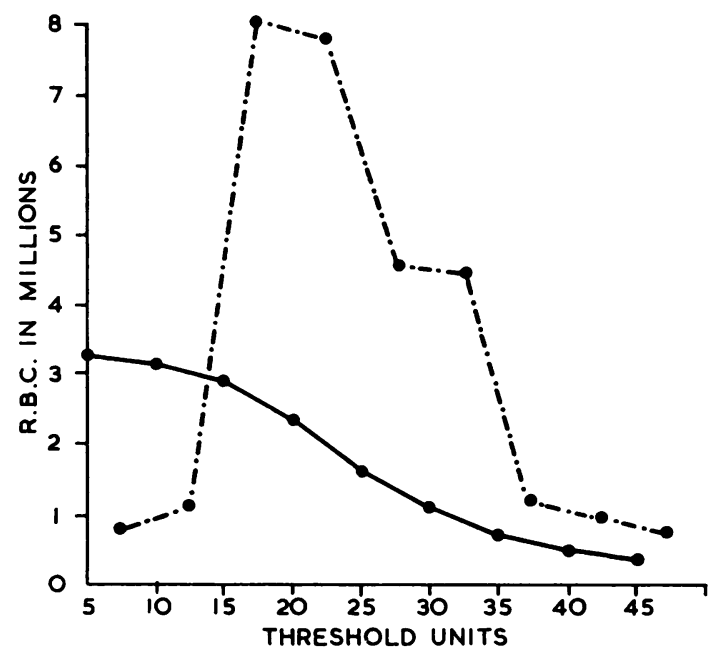

FIG. 10

FIG. 6. Macrocytic anaemia (folic-acid deficiency, druginduced). Hb $38 \%$; P.C.V. $19 \%$; R.B.C. $1 \cdot 3$ m.; M.C.H.C. $30 \%$; M.V.C. $140 \mu^{3}$; colour index 1.46 .

FIG. 7. Pernicious anaemia. Hb $67 \%$; P.C.V. $28 \%$; R.B.C. 2.34 m.; M.C.H C. $33 \%$; M.C.V. $119 \mu^{3}$ : colour index $1 \cdot 32$.

FIG. 8. Macrocytic anaemia. Hb 62\%; P.C.V. $28 \%$; R.B.C. 2.26 m.; M.C.H.C. $33 \%$; M.C.V. $124 \mu^{3}$; colour index $1 \cdot 38$.

FIG. 9. Case G.B. 10 days after beginning treatment. Reticulocyte response peak on R. Hb $53 \%$; P.C.V. $26 \%$; R.B.C. 3.37 m.; M.C.H.C. $30 \%$; M.C.V. $78 \mu^{3}$; colour index $0 \cdot 78$.

FIG. 10. Case G.B. five days after preceding figure. Reticulocyte peak merging into main body. $\mathrm{Hb} 62 \%$; P.C.V. $28 \%$; R.B.C. 3.49 m.; M.C.H.C. $32 \%$; M.C.V. $80 \mu^{3}$; colour index 0.89. 


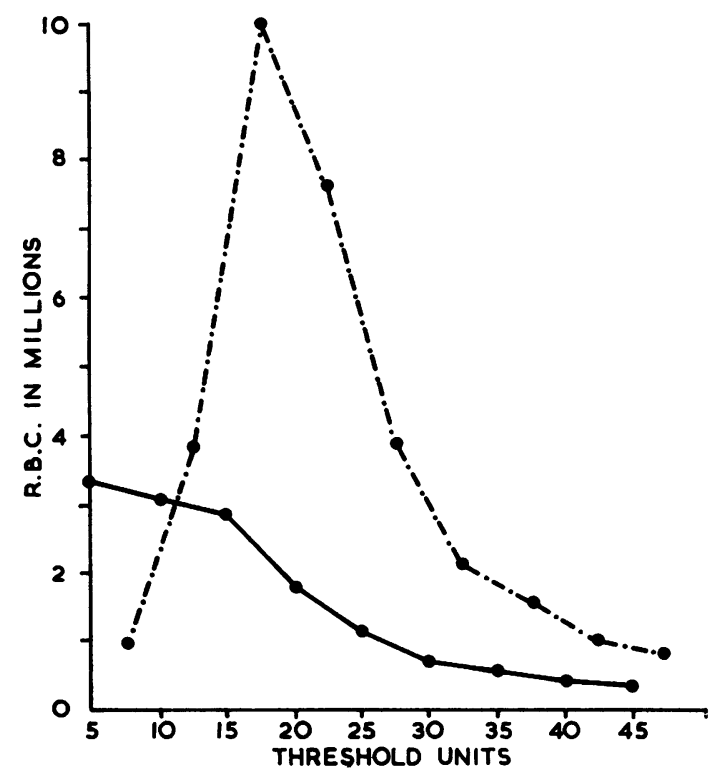

FIG. 11. Case G.B. four days after Fig. 10. Reticulocytes absorbed into main mass. Hb $64 \%$; P.C.V. $32 \% ;$ R.B.C. 3.41 m.; M.C.H.C. $29 \%$; M.C.V. $92 \mu^{3}$; colour index 0.92 .

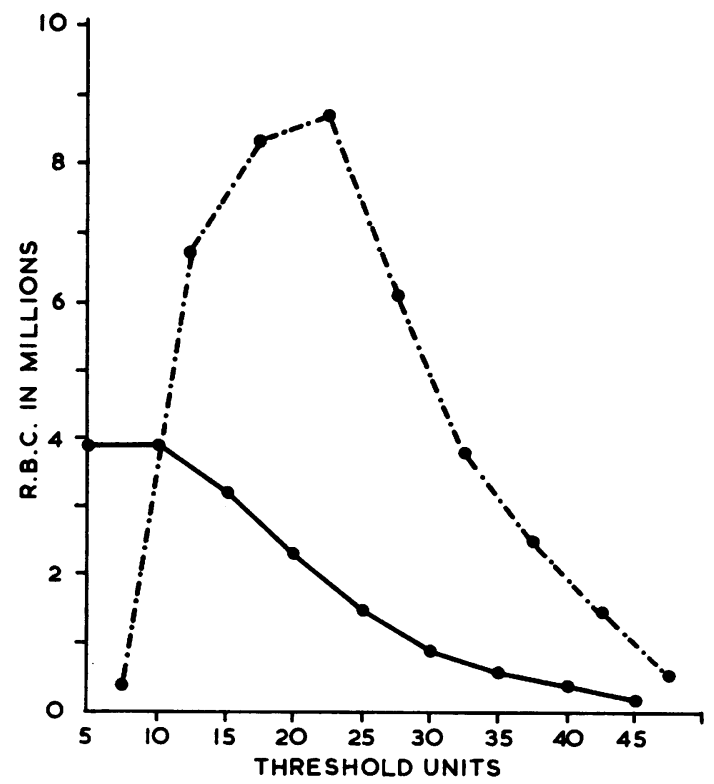

FIG. 12. Case G.B. 18 days after Fig. 11. Hb $84 \%$; R.B.C. $4.07 \mathrm{~m}$. ; return to normal.

\section{COUNTING OF WHITE CELLS}

White cell counts are reproducible on this machine with a standard error of $7.5 \%$ (Richar and Breakell, 1959) and duplicate counts can be run off at the rate of one a minute. Against this must be set the additional work involved in preparing diluting fluids, and additional care in pipetting, which is now the greatest error.

\section{TECHNICAL DETAILS}

ANTICOAGULANTS As a routine we have used venous blood taken into plastic bottles containing Anti-clot ${ }^{1}$, a heparin-like substance. Blood treated with Wintrobe's anticoagulant very occasionally causes the orifice to become blocked due to oxalate crystals. We have found that the total number of red cells remains constant in whole blood treated with anti-clot and kept at $4^{\circ} \mathrm{C}$. for 36 hours.

DILUTION OF BLOOD FOR COUNTING The dilutions are made in two steps. The first is $1 / 500$ made by pipetting $20 \mathrm{cu}$. micro-litres of blood into $10 \mathrm{ml}$. of $0.9 \%$ albuminsaline. From this a second dilution is made of $1 / 50,000$ by taking $0.2 \mathrm{ml}$. into a further $20 \mathrm{ml}$. of albumin-saline. The first dilution is then lysed with Saponin and used for the white cell count, the second dilution for the red cell count. When wiping the tip of the pipette, small pieces of lens tissue are most satisfactory.

Red cells remain stable in a dilution of $1 / 500$ in pure $0.9 \%$ saline or in albumin-saline for 20 hours, but in a dilution of 50,000 in pure $0.9 \%$ saline red cells swell and lyse (see Fig. 13). A phosphate buffer solution containing sequestrene (see Fig. 14) was inferior to $0.9 \%$ saline containing 1 part in 30,000 of albumin (see Fig. 15). The graph of R.B.C.s in saline shows clearly the tendency of red cells to swell and lyse.

We conclude that the total red cell count is reproducible after dilution in albumin-saline for seven hours, although four hours is a good working optimum; when the red cell size distribution is to be scanned, as short a time as possible should elapse.

PREPARATION AND DISPENSING OF DILUTING FLUIDS Stock $25 \%$ solution A. $R$. sodium chloride is bottled in amounts of 2 litres with a plastic giving-set used as an exit. Glassdistilled water is used to dilute it to a concentration of $0.9 \%$. This is titrated in bulk, filtered through a sintered glass filter filler (Matburn unit no. F4 with 4P filter), bottled in $540 \mathrm{ml}$. amounts in British Standard blood transfusion bottles, and autoclaved at $20 \mathrm{lb}$. for 20 minutes. The closures must be tightly screwed before autoclaving or the concentration of salt will rise, and it is safer to do this overnight to allow it to cool slowly. One part in 30,000 of bovine albumin is then added, and the bottle suspended upside down above an automatic pipette (10 or $20 \mathrm{ml}$.) connecting it by a plastic giving-set. For counting, we dispense $10 \mathrm{ml}$. amounts daily into

${ }^{1}$ Clinton Laboratories, California. 


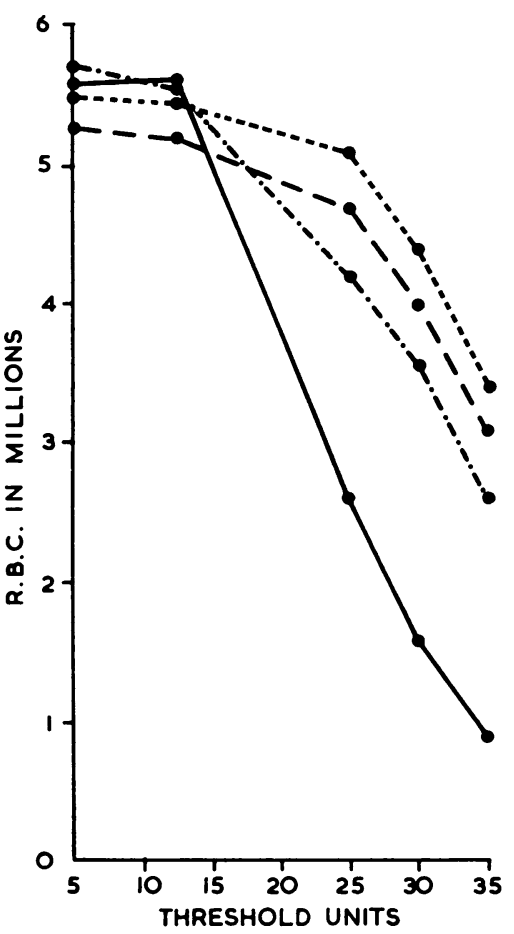

FIG. 13

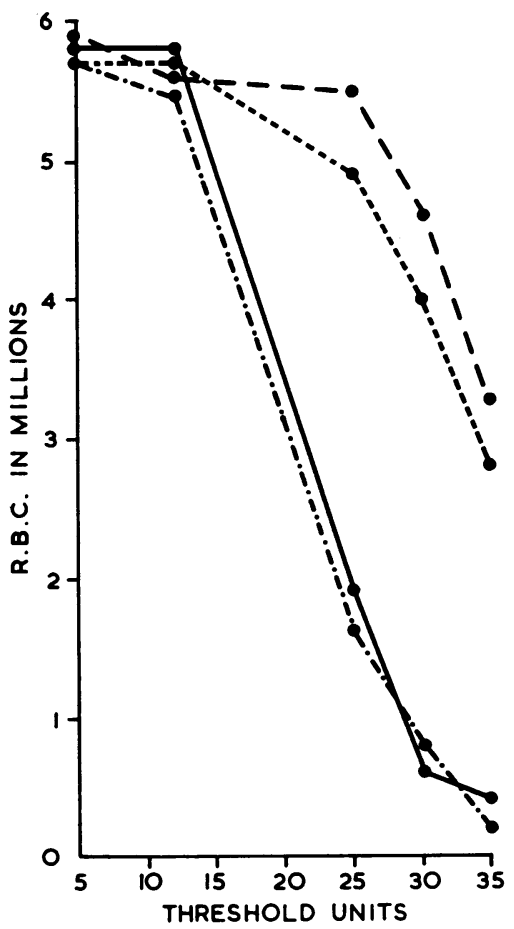

FIG. 14

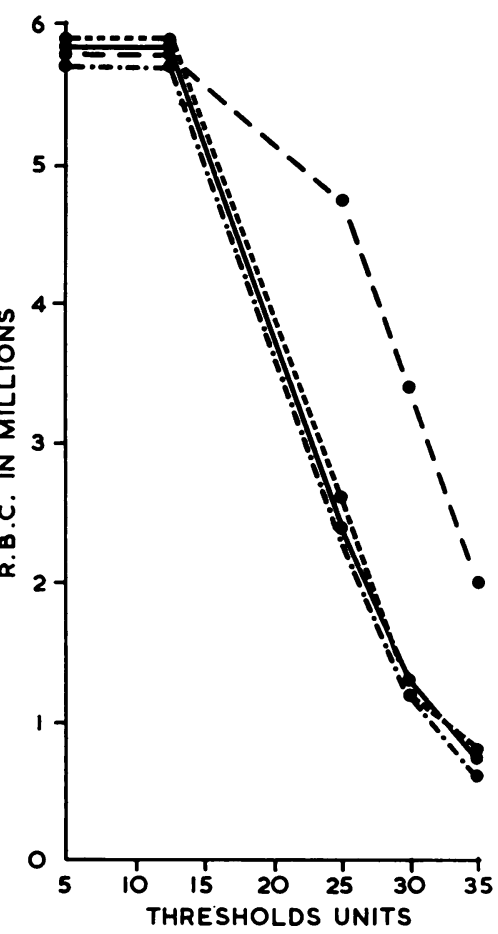

FIG. 15

FIG. 13. Effect of pure $0.9 \%$ saline on R.B.C.s in dilution of 1 in 50,000, showing threshold curves at intervals of two hours (continuous line), three hours (short dashes), seven hours (dots), and 20 hours (long dashes). There is a progressive increase in large cells, i.e., swelling, until at 20 hours haemolysis is evidenced by a reduction in total numbers.

FIG. 14. Effect of phosphate buffered saline with sequestrene on R.B.C.s, as in Fig. 13. Stable up to three hours. Legend as for Fig. 13.

FIG. 15 .

Effect of albuminized saline on R.B.C.s. Stable up to seven hours, total stable up to 20 hours.

glass flat-bottomed tubes of about $30 \mathrm{ml}$. capacity with plastic stoppers. Albumin-saline produced by this method gives a blank count at a threshold level of about 300 R.B.C.s per $0.5 \mathrm{ml}$. Commercially prepared saline usually gives counts of under 250 per $0.5 \mathrm{ml}$. Regular checks should be made of the blank count as this gives an indication of whether the apparatus is becoming contaminated.

CLEANING OF GLASSWARE After use the glass pots are rinsed in tap water, soaked in $0.3 \%$ Haemosol for 30 minutes, rinsed in distilled water, and dried upside down in an oven. The plastic stoppers are similarly cleaned, but dried at $37^{\circ} \mathrm{C}$. Pipettes are rinsed in Haemosol, distilled water and ether-meths, and dried.

WHITE CELL COUNTING White cells are counted in the 1/500 dilution after the addition of Saponin.
SAPONIN This is a $2 \%$ solution of white Saponin (Hopkin and Williams) of which 1 drop is added to the first dilution, after the preparation of the second dilution, to lyse the red cells. This takes four minutes, and the white cells should then be counted, as after a further interval they also begin to disappear.

We are indebted to Messrs. Coulter for information and technical data, to Mrs. R. Harris for clerical assistance and to the Wessex Regional Board for financial assistance and encouragement.

\section{REFERENCES}

Brecher, G., Schneiderman, M., and Williams, G. Z. (1956). Amer. J. clin. Path., 26, 1439.

Magath, T. B., and Berkson, J. (1960). Ibid., 34, 203.

Richar, W. J., and Breakell, E. S. (1959). Ibid., 31, 384. 


\section{Broadsheets prepared by the Association of Clinical Pathologists}

The following broadsheets (new series) are published by the Association of Clinical Pathologists. They may be obtained from Dr. R. B. H. Tierney, Pathological Laboratory, Boutport Street, Barnstaple, N. Devon. The prices include postage, but airmail will be charged extra.

3 The Detection of Barbiturates in Blood, Cerebrospinal Fluid, Urine, and Stomach Contents. 1953. L. C. NICKOLLS. 1s.

4 The Estimation of Carbon Monoxide in Blood. 1953. D. A. STANLEY. 1s.

5 The Identification of Reducing Substances in Urine by Partition Chromatography on Paper. 1953. G. B. MANNING. $1 \mathrm{~s}$.

6 The Paul-Bunnell Test. 1954. R. H. A. SwaIN. 1s.

7 The Papanicolaou Technique for the Detection of Malignant Cells in Sputum. 1955. F. HAMPSON. 1s.

13 The Identification of Serotypes of Escherichia coli Associated with Infantile Gastro-enteritis. 1956. JOAN TAYLOR. $1 \mathrm{s.}$

14 The Determination of Serum Iron and Serum Unsaturated Iron-binding Capacity. 1956. ARTHUR JORDAN. 1s.

16 Preservation of Pathological Museum Specimens. 1957. L. W. PROGER. 1s.

17 Cultural Diagnosis of Whooping-cough. 1957. B. W. LACEY. $1 \mathrm{~s}$.

18 The Rose-Waaler Test. 1957. c. L. GREenBURY. 1s.

20 Investigation of Porphyrin/Porphyria. 1958 (reprinted 1962). C. RIMINGTON. 2 s.

23 The Dried Disc Technique for Bacterial Sensitivity Tests. 1959. R. W. FAIRBROTHER and J. C. SHERRIS. Is.

24 Safe Handling of Radioactive Tissues in the Laboratory and Post-mortem Room. 1959. R. C. CURRAN. $1 \mathrm{s.}$

26 The Periodic Acid-Schiff Reaction. 1959. A. G. E. PEARSE Is.

28 Daily Fatty Acid Excretion. 1960. A. C. FRAZER. 2 s.

29 The Preparation of Bone for Diagnostic Histology. 1960. D. H. COLLINS. 2s.
30 Control of Accuracy in Chemical Pathology. 1961. G. H. GRANT. 4s.

31 Investigation of Haemorrhagic States with Special Reference to Defects of Coagulation of the Blood. 1961. E. K. BLACKBURN. 4s.

32 Detection of Resistance to Streptomycin, P.A.S., and Isoniazid in Tubercle Bacilli. 1961. R. CRUICKSHANK and S. M. STEWART. $2 s$.

33 The Laboratory Detection of Abnormal Haemoglobins. 1961. H. LEHMANN and J. A. M. AGER. 4s.

34 Titration of Antistreptolysin O. 1961. H. GOODER and R. E. O. WILLIAMs. $2 s$.

35 The Estimation of Faecal 'Urobilinogen'. 1961. C. H. GRAY. $2 s$.

36 Quantitative Determination of Porphobilinogen and Porphyrins in Urine and Faeces. 1961. C. RIMINGTON. 3s. 6d.

37 The Paper Electrophoresis of Serum and Urinary Proteins. 1961. G. FRANGLEN and N. H. MARTIN. 4s.

38 The Augmented Histamine Gastric Function Test. 1961. M. LUBRAN. 2s.

39 Investigation of Haemolytic Anaemia. 1961. J. G. SELWYN. $2 s$.

40 Short Term Preservation of Bacterial Cultures. 1962. E. Joan Stokes. 2s.

41 Serological Tests for Syphilis. 1962. A. E. WILKINson. 6s.

42 The Determination of Glucose 6-Phosphate Dehydrogenase in Red Cells. 1962. T. A. J. PRANKERD. 2s.

43 Mycological Techniques. 1962. R. W. RIDDELL. 3s. 6d.

\section{CORRECTIONS}

In the paper 'Observations on the use of the Coulter model D electronic cell counter in clinical haematology' (Blades, A. N., and Flavell, H. C. G., J. clin. Path., 16, 158-163) Fig. 9 should be Fig. 8 and vice versa. Also on page 163, col. 1, line 3 should read 'gives a blank count at a threshold level of 5 of about 300 per $0.5 \mathrm{ml}$.'
In the book reviewed on page 185 by E. S. Anderson Of ENTEROBACTERIACEAEINFEKTIONEN the sentence '(There is a misprint . . . 1923-1928.)' should read '(There is a misprint in the text at this point, the English figures being erroneously quoted as covering the period 1933-38 instead of 1923-1938.)' 